\title{
COMMENTS
}

\section{FAIRNESS AND A CONSUIMPTION-TYPE OR CASH FLOW PERSONAL INCOME TAX}

\author{
Alvin C. Warren, Jr.
}

In a recent article, Professor William Andrews proposed rejection of the accretion tax ideal in favor of a consumption-based tax scheme. One of his reasons for preferring the consumption-type tax model was its neutrality between persons who spend their income currently and those who save for future consumption. In this Comment, Professor Warren suggests that the neutrality of the consumption-type tax is obtained at the cost of allowing income from wealth to escape taxation. Finding the consumption-based tax to be analagous, if not identical, to a tax on wages alone, he rejects it as an insufficient compromise of the varions legitimate objectives of a basic tax system.

W

ILLIAM Andrews has recently set forth a model of a consumption-type personal income tax as an alternative to the existing tax and the prevailing accretion ideal. ${ }^{1}$ Under Andrews' approach, individuals would be taxed on the basis of their consumption, rather than the sum of consumption and accumulation. To accomplish that result, the personal income tax would be levied on a simple cash flow basis: business and investment expenditures (including capital outlays) would be deductible when made, while business and investment receipts (including returns of capital) would be immediately and fully includable in taxable income. ${ }^{2}$ Professor Andrews argues that such a tax not only would be superior to the current income tax, but that it would even be preferable to a truly comprehensive accretion-type income tax. ${ }^{3}$ Considerations of administrative simplicity, economic efficiency, and fairness all lead him to that conclusion. It is the last part of his argument - that a consumption-type income

* Associate Professor of Law, Duke Law School; Visiting Associate Professor of Law, University of Pennsylvania Law School (1974-75). B.A., Yale, 1966; J.D., University of Chicago, I969. The author would like to thank his colleague, Daniel Halperin, for his comments.

${ }^{1}$ Andrews, A Consumption-Type or Cash Flow Personal Income Tax, 87 Harv. L. Rev. III3 (I974) [hereinafter cited as Andrews]. Expenditure taxation has a rich intellectual history among economists. See id. at III7 n.7.

2 See id. at Ir49.

3 The classic case for the accretion model is H. Simrons, Personal Income Taxatron (1938). See also sources cited in Andrews at III3 n.I. 
tax is fairer than a true accretion-type income tax - which is examined here. ${ }^{4}$

\section{Accumulation as Consumption Foregone}

Andrews begins his analysis of the fairness of a tax on income received but not consumed by characterizing accumulation as consumption foregone, and offers two reasons for its exclusion from the tax base given that characterization. First, we are told that the "primary, intended, real effect of any general revenueraising tax is to curtail some part of the private consumption of economic resources that would otherwise occur, in order to free those resources for public use, including redistribution to the poor." s Since "the purpose is to curtail consumption," it is "presumptively fair" to distribute the burden of the tax "in relation to levels of consumption prior to the imposition of the tax." ${ }^{\circ}$

This argument confuses the effect of a tax with the base for measuring tax liability. Assuming a tax will be paid with resources the taxpayer would otherwise consume ${ }^{7}$ does not indicate whether it would be fairer to levy the tax on the basis of accretion, consumption, wealth, or something else. If we thought a tax levied on the basis of waistlines were fair, it could still be collected in dollars (that is, resources that would otherwise be consumed) rather than pounds of flesh. ${ }^{8}$ Later in his article, Andrews himself advocates, as a matter of fairness, a tax on the transfer of property between generations, ${ }^{0}$ a base quite different from levels of consumption.

If, however, as Andrews suggests, the curtailment of consumption is not only the effect of any general revenue-raising tax, but also its purpose, then it might follow that the tax burden should be allocated in accordance with consumption levels. But why should it be assumed that the purpose of any general revenueraising tax is to curtail consumption, as opposed to curtailing consumption and accumulation, redistributing wealth, or something else? Andrews does not indicate the premise on which his assump-

${ }^{4}$ As Andrews' equity and efficiency arguments are presented together, some of their common components will necessarily be discussed in the text, but no conclusion is intended regarding the merits of the efficiency analysis.

${ }^{5} I d$. at $1165-66$.

${ }^{6} I d$.

${ }^{7}$ Andrews concedes that some persons may pay taxes without reducing current consumption, but maintains that a consumption-type tax will be fair "because it will impose the same increase in the price for maintaining any particular level of consumption ...."Id. at II 66-67.

${ }^{8}$ The waistline example is taken from E. Rolph \& G. Break, Public Finance I79 (I96r).

${ }^{9}$ Andrews at $\mathrm{Ir} 72$. 
tion rests, and without some acceptable explanation, assertions regarding the tax's purpose are not persuasive in weighing the relative fairness of alternative tax bases. And even if reduction of consumption were conceded to be the principal objective of taxation, it might still be possible to accomplish that goal by levies on bases other than consumption alone. ${ }^{10}$ But, perhaps by stating that a consumption tax is "presumptively" fair, it is only meant that the postulated purpose and effect of the tax is a tentative measure of its fairness, subject to reevaluation when other equity goals, such as mitigation of disparities in wealth, are considered. In any event, the ultimate fairness of a basis for taxation simply cannot be derived from what is collected when the tax is imposed.

The second reason for not taxing accumulation when it is characterized as consumption foregone is that accumulation generally represents the market value of the "excess of what one has contributed to production in a particular period, in labor or capital or both, over what he has withdrawn for private consumption during that period, and there is no reason to tax a person on that excess." "11 The only explanation given by Andrews for not taxing it is to quote Hobbes' well-known question: ${ }^{12}$

For what reason is there that he which laboureth much, and sparing the fruits of his labour, consumeth little, should be more charged than he that living idlely, getteth little, and spendeth all he gets; seeing the one has no more protection from the Common-wealth, than the other?

While Hobbes' question is certainly pertinent, it hardly demonstrates that there is no reason to tax accumulation. Nor is Hobbes' original rationale for taxation - "to defend private men in the exercise of their several trades, and callings" 13 - much help in deciding the fairest means of financing modern government. Since Hobbes' sovereign would use tax receipts to protect "the enjoyment of life, which is equally dear to poor and rich," the poor would be as indebted to the government for defense of their lives as the rich "saving that the rich, who have the service of the poor, may be debtors not only for their own persons but for many more." 14 Hobbes' argument not only contemplates a considerably narrower range of governmental functions than that prevailing in contemporary democracies, but it also assumes that taxes are to be levied in accordance with benefits received from the govern-

\footnotetext{
${ }^{10}$ See A. Prest, Public Finance i29 (Ig6o).

11 Andrews at II66.

${ }^{12}$ T. HobBes, Leviathan 298 (A. Lindsay ed. I950).

${ }^{13} I d$.

${ }^{14} I d$.
} 
ment - a standard long since replaced by ability to pay, whether that means accretion, consumption, wealth or whatever. ${ }^{15}$

More importantly for present purposes, the second reason for not taxing accumulation as consumption foregone suffers the fatal defect that in our society "the excess of what one has contributed to production" is not lost to the contributor. Rather, as Andrews puts it, a saver retains "the claim against future output represented by his accumulated income." "10 since savings remain available for the accumulator's future disposition. Thus accumulation is not really "consumption foregone" after all. It is consumption deferred, and we must turn to an examination of Andrews' argument for its exclusion from the tax base on that characterization.

\section{Accumiulation as Consumption Deferred}

\section{A. Discrimination Against Future Consumption}

What Andrews calls "the most sophisticated argument" in favor of a consumption-type income tax is that such a tax is "more appropriate because it ultimately imposes a more uniform burden on consumption, whenever it may occur, than does an accretiontype tax." 17 Neutrality with respect to consumption is important for Andrews "not only because it promotes efficiency in the allocation of income, but because it keeps the tax from bearing more heavily on one person than another on account of differences in need or taste for particular goods or services, now or in the future." 18

While Andrews is clearly right in asserting that an accretiontype tax creates a heavier ultimate burden in relation to future consumption than in relation to present consumption, his selection of taxpayers to illustrate the discrimination is somewhat puzzling. The example given is that of a taxpayer who puts aside $\$ 100$ of current earnings for retirement. Invested at $9 \%$ compound interest, that sum will grow to $\$ 800$ after 24 years. A consumption tax of $33 \%$ would leave the retiree with $\$ 533$ to spend while an accretion tax of $33 \%$ imposed on the initial $\$ 100$ and on the annual increase in value would leave only $\$ 267$ after 24 years. ${ }^{10}$ Andrews suggests that the "logic" of a consumption-type tax is that a $33 \%$ taxpayer who would have had $\$ 800$ to spend in the

\footnotetext{
${ }^{15}$ The Hobbesian view also assumes it is better to contribute to the common pool than to withdraw from it, a judgment embraced in N. KaLDOR, AN ExPENDITURE TAX 53 (x955) and, more cautiously, in Andrews at II 74 .

${ }^{16}$ Andrews at 1167 .

${ }^{17} I d$.

${ }^{18} \mathrm{Id}$. at $\mathrm{I} \times 67-68$.

${ }^{10}$ Id. at $x 168$.
} 
absence of tax should have $\$ 533$ after tax whatever combination of earnings and savings may have gone to produce the $\$ 800$. An accretion tax is "discriminatory" because it will leave less for the retiree after 24 years than for another taxpayer with $\$ 800$ of current income, presumably in year 25 .

If Andrews' point is that otherwise similarly situated taxpayers are taxed differently solely because of differences in preferences "for particular goods or services, now or in the future," these taxpayers are neither otherwise similarly situated nor do they reveal different preferences in year 25 . Relative to the taxpayer with current income, the retiree does not defer consumption: they both consume in year 25 . Furthermore, the fact that the two taxpayers have different earning streams, and have not been presented with the same options before year 25 , suggests their positions are not strictly comparable. The retiree may (or may not) pay for his consumption out of saved compensation while the taxpayer with current earnings may (or may not) pay for his consumption out of current income. But even if one pays with saved compensation while the other pays with current earnings, that does rot establish discrimination since, as Andrews elsewhere indicates, fairness in taxation is to be measured between individuals, not funds. ${ }^{20}$

The two taxpayers are, of course, in identical positions with regard to consumption since they consume the same amount in year 25. If the appropriate index of equality for tax purposes is concluded to be consumption, then any tax, including an accretiontype tax, that treats equal consumers differently is discriminatory. However, that discrimination cannot be used to support the conclusion that the appropriate index of equality is consumption, as that conclusion was a necessary predicate for the finding of discrimination. To avoid circularity in the argument, a finding that the accretion-type tax discriminates among taxpayers on the basis of their preferences for present and future consumption must not depend on a prior assumption that consumption is the fairer tax base.

The discrimination of an accretion-type tax against taxpayers who have relatively greater preferences for future consumption can be clarified by comparing two workers, both of whom earn $\$$ roo in an initial year $\mathrm{r} .{ }^{21}$ In a world without taxes, each has the

\footnotetext{
${ }^{20} \mathrm{Id}$. at II33.

${ }^{21}$ To make comparisons easier, the examples in the text will follow as closely as possible those in Andrews. Accordingly, interest will be calculated by the rule of thumb used there, see id. at II 25 n.20, with the results rounded. Also following Andrews, the tax rate will be expressed as if the tax were part of the tax base, see id. at III9 n.Io, and the appropriate comparison will be assumed to be between equivalent rate taxes rather than between taxes yielding equivalent
} 
choice of consuming $\$ 100$ in that year or $\$ 800$ after 24 years (with interest compounding at $9 \%$ ). The price of consumption in the initial year relative to consumption after 24 years is $100 / 800$, or I/8. Imposition of a consumption-type income tax leaves the ratio at $67 / 533$, or $I / 8$. If one taxpayer spends in year I and the other spends in year 25 , both consume less after taxes, but their relative positions remain as they were in the non-tax world. Imposition of an accretion-type tax changes the ratio to $67 / 267$, or $I / 4$, so the taxpayer with a greater relative preference for future consumption is taxed more heavily. Hence, although neither tax discriminates on the basis of "need or taste for particular goods or services, now or in the future," 22 an accretiontype tax does discriminate against taxpayers with relatively greater preferences for future, as compared with present consumption.

This discrimination - which John Stuart Mill called a double tax on savings ${ }^{23}$ - results from the fact that imposing a tax on accretion reduces the after-tax return on invested savings. ${ }^{24}$ Despite the existence of a lengthy historical debate in rebuttal of Mills' position, ${ }^{25}$ it seems to be beyond present doubt that relative positions of taxpayers are changed by an accretion-type, but not a consumption-type, tax. The traditional counterargument - that an accretion-type tax is discriminatory only if one embraces the consumption model ${ }^{26}$ - is not persuasive because the accretiontype tax discriminates among taxpayers relative to the no-tax world, whereas the consumption-type tax does not. ${ }^{27}$

revenues. One practical problem with substituting a consumption-type tax for the present income tax is that the new tax would increase future revenues at the expense of current revenues. If the Treasury were unwilling to accept an immediate decline in tax receipts, rates under a consumption-type tax would have to be raised to maintain revenue yield. For calculation of comparable rates where the $\operatorname{tax}$ base is net of tax and where revenues are assumed to be equivalent, see N. KaLdOR, supra note 15 , at 232 ; A. PREST, supra note 10, at $48 \mathrm{n} . \mathrm{I}, 80-8 \mathrm{I}$; C. Shoup, Public Finance 346 (I969).

Examples similar to that in the text can be found in R. Goode, The Individun Income TaX 25-28 (I964); A. Prest, supra note Io, at 80; W. Vickery, AgendA for Progressive Taxation 336 (I947).

${ }^{22}$ Andrews at $1167-68$ (emphasis added). A selective excise tax, on the other hand, would discriminate among particular goods and services.

${ }^{23}$ J.S. MIIL, Principles of Political Economiy, bk. V, ch. II, $\S 3$ (gth ed. 1895).

${ }^{24} I d$.

${ }^{25}$ See Andrews at 1168 n.I22.

${ }^{26}$ See, e.g., Musgrave, A Further Note on the Double Taxation of Savings, 29 AM. ECON. Rev. 549 (I939).

${ }^{27}$ On the other hand, if saving were considered to offer imputed expenditures on such intangibles as prestige, power, and security, a consumption-type tax would discriminate in favor of that form of expenditure. See C. SHOUP, supra note $2 I$, at $352 ; c f$. pp. $94 \mathrm{I}-42$ infra. 
Although the discrimination occasioned by an accretion-type tax seems real enough, it is probably overstated in the preceeding examples because of the implicit assumption that such a tax will not affect the gross rate of interest. Invested savings in all examples up to this point have earned a gross rate of return of $9 \%$ with or without a tax; only the net return fell, from $9 \%$ to $6 \%$, when a $33 \%$ accretion-type tax was imposed. But if imposition of the tax also raises the gross rate of return, the discrimination is reduced or eliminated. Assume again that the pretax interest rate were $9 \%$, so the retiree who saved and invested $\$ 100$ in year I would have $\$ 800$ after 24 years, and the ratio between the prices of present and future consumption would be $100 / 800$, or $1 / 8$ in a world without taxes. If imposition of an accretion-type tax caused the gross interest rate to rise to $13.5 \%$ (because savers continued to require a $9 \%$ net return while borrowers' demand for saved funds was relatively fixed), imposition of a $33 \%$ accretion-type tax would present our wage earners with the choice of consuming $\$ 67$ in year I or $\$ 533$ after 24 years, maintaining the ratio at $67 / 533$ or $1 / 8$. A consumption-type income tax would also leave the wage earners with the choice between $\$ 67$ in year I or $\$ 533$ after 24 years since the net rate of return, here $9 \%$, would be the same as the gross rate of return when annual yield is not taxed. Finally, a retiree who saved and invested \$IOO in year I would have the same amount after taxes, $\$ 533$, to consume 24 years later as would a taxpayer with $\$ 800$ in current income. Thus, if the rise in gross interest rates fully offsets the tax imposed on income producing assets, an accretion-type tax would not discriminate against future consumption, whether equal earners or equal consumers are compared.

Unfortunately, there is no a priori method of determining what will be the actual effect of an accretion tax on rates of return. The impact of accretion-type taxation on the level of investment and rates of return will depend on the characteristics of the demand for, and supply of, investable funds. ${ }^{28}$ Without knowing those characteristics it is impossible to identify the effects of an accretion-type tax on the interest rate and, accordingly, the amount of discrimination occasioned by the tax. One might nevertheless respond that elimination of an accretion-type tax is highly unlikely to cause interest rates to fall by the full amount of the tax, as in my extreme example, so some discrimination against future consumption is bound to remain..$^{29}$ Yet the quantum of discrimination is surely relevant for Andrews' fairness, as well as his efficiency, analysis if the discrimination is to be balanced

${ }^{28}$ See J. Due \& A. Friediaender, Government Finance - Economics of the Public Sector 30I-03 (5th ed. I973).

${ }^{29}$ See C. SHoup, supra note $2 \mathrm{I}$, at 346 . 
against equity arguments in favor of an accretion-type tax. Though some discrimination will occur as a result of an accretiontype tax, it may be considerably overstated by examples which assume no change in the gross rate of interest.

\section{B. The Equivalence of a Consumption-Type Income Tax and a Tax on Wages Alone}

Andrews carefully demonstrates that when tax rates are constant, deferral of a tax on an investment is equivalent to exemption of the investment's subsequent yield and appreciation. ${ }^{30} \mathrm{He}$ also asserts at several points that the difference between an accretion-type and a consumption-type tax is essentially one of deferral. $^{31}$ Considering those two statements together leads to the somewhat surprising conclusion that when tax rates are constant, a consumption-type personal income tax is the equivalent of a tax which permanently exempts all income from property, that is, a tax only on wages.

I. Assuming Constant Tax Rates. - That a consumptiontype tax is equivalent to a tax on wages alone when tax rates remain constant can be seen by applying a wage tax of $33 \%$ to Andrews' retiree in the initial year, so he has only $\$ 67$ left to spend or save in that year. If saved and invested at $9 \%$, that amount will produce $\$ 533$ to spend after 24 years since, by hypothesis, the wage tax does not reach income from property. That is exactly the result for the retiree in Andrew's example, where nothing would have been taxed in the initial year because there was no consumption, and the full $\$ 800$ taxed when consumed 24 years later. Thus, if tax rates are constant, a wage tax, which does not reach income from property, will always leave taxpayers in the same positions as a consumption tax, which defers taxation when funds are saved. ${ }^{32}$

It may be objected that a consumption-type income tax is not equivalent to a wage tax because under the former even an idle taxpayer who has never earned wages and who lives entirely on interest receipts will have to pay taxes as the interest is spent.

${ }^{30}$ Andrews at $1123-28,1167$.

${ }^{31} I d$. at III5, II $20,1124, I 167$.

${ }^{32}$ Although the net of tax results will always be the same, it may be objected that there is a formal difference between the two taxes in that wage taxes are paid immediately, here in year $\mathrm{I}$, while the payment of consumption taxes is delayed, here until after 24 years. The difference in the date of payment of the two taxes can be eliminated by giving the wage earner the opportunity to defer his wage tax until consumption, with income earned on the deferred tax going to the government. In terms of our examples, the wage earner could either pay a $\$ 33$ wage tax in year I or invest that $\$ 33$ for 24 years at $9 \%$, when $\$ 267$ would be due the government as a deferred wage tax, again leaving $\$ 533$ for consumption. 
But if the interest-producing asset were purchased with wages earned after the imposition of the consumption-type tax, taxation of the idle taxpayer's consumption will again produce exactly the same result as would earlier wage taxation of the individual whose wages were invested to provide the idler with interest. Andrews' ideal consumption-type tax would provide that a transfer of property by gift or bequest would not be a taxable event, so deferral - the equivalent of exemption from taxation of income from property - can continue for generations, until consumption occurs. ${ }^{33}$ If the interest-producing property had been purchased with wages saved under the current income tax, a transitional problem would arise in that taxation of the wage-earner, who would have received no deduction for saving under the existing tax, and taxation of the consumer would be double taxation to a supporter of the consumption model. As a partial solution, Andrews suggests exempting cash balances from the consumption tax if their accumulation was recently taxed at ordinary income rates. ${ }^{34}$ The problem of what to do about consumption where accumulation has already been taxed is, in any event, a purely transitional one which does not undermine the basic equivalence of the wage and consumption-type taxes.

Finally, it may be asserted that the equivalence between deferral on investment and exemption of income or "yield" from property fails if the income contains elements of windfall investment profit. Andrews makes this point in distinguishing "windfall profit" from "simple investment yield." 35 Presumably the former means unanticipated appreciation while the latter includes only anticipated yield. Under that definition, all our examples thus far have been restricted to "simple investment yield."

Suppose that for some totally unanticipated external reason, the investment asset purchased by the retiree for $\$ 100$ in the initial year doubled in value at once. The resulting $\$ 200$ invested at $9 \%$ would yield $\$ 1600$ after 24 years, and a consumption tax of $33 \%$ applied at that time would leave \$1066 after taxes. A wage tax of $33 \%$ in the initial year would leave $\$ 67$ after taxes

\footnotetext{
${ }^{33}$ Andrews at 1162 .

${ }^{34}$ Andrews is, however, unwilling to apply this solution to all investment assets purchased before the transition to a consumption-type tax, explaining only that to do so "would impair the integrity of the consumption-type tax too much and too long, and often with too little real justification." Id. at II77 n.I4O. Failure to give full credit for the pretransition basis of investment assets would, however, seem to involve the "double taxation of saving" and discrimination against deferred consumption found so objectionable in the accretion-type tax.

${ }^{35} I d$. at $1182-83$ n.I5o. At other points, however, Andrews indicates deferral is equivalent to exemption of investment income when both "yield and appreciation" (all "subsequent profit") are exempted, id. at Ix26, II67, a view which is consistent with the position taken in the text here.
} 
to invest in that year, $\$ 133$ after the unanticipated doubling, and $\$ 1066$ after 24 years at $9 \%$. Thus, the equivalence between a wage tax and a consumption tax holds even though the exempted "yield" contains elements of "windfall profit."

This equivalence compels reevaluation of Andrews' conclusion that source discrimination is no more appropriate under a consumption-type tax than under an accretion-type tax. Thus, exemption of interest on state and municipal bonds is said to be a departure from either ideal, ${ }^{36}$ but as Andrews also indicates, a deduction for investment in municipal bonds reduces the effective rate of tax on that interest to zero no less certainly than does the exemption. ${ }^{37}$ While it offers no justification for source discrimination among various kinds of wages or property income, the consumption ideal thus effectively exempts all property income from taxation while including all income from personal services. This result should not be too surprising once it is recalled that Andrews' proposal is designed to eliminate the tax on benefits that flow from deferring consumption. Since potential consumption increases over time only to the extent one invests in accretionproducing assets, those benefits are none other than income from property.

2. When Tax Rates Are Not Constant. - If different tax rates are applicable, a wage tax and a consumption-type tax are no longer precisely equivalent. The retiree who earns $\$ 100$ and pays a $33 \%$ wage tax in year I will have $\$ 533$ left after 24 years at $9 \%$, but if the consumption tax rate after 24 years were only $20 \%$, that tax would leave $\$ 640$ for consumption. Such a disparity in rates between years may arise because the statutory schedules have been changed, because the taxpayer is subject to a different rate under a graduated tax, or because different taxpayers are involved.

The only relevant difference between a consumption-type personal income tax and a wage tax is thus the disparity that arises when tax rates are not constant. ${ }^{38}$ But, identification of a

\footnotetext{
${ }^{36} I d$. at 1178 .

${ }^{37} I d$. at $\operatorname{rr} 8 \mathrm{r}$ n.r 49 .

${ }^{38}$ The taxes will produce different results if ( 1 ) accumulation continues forever so there is never any consumption to tax; (2) consumption occurs without there ever having been prior earnings to tax; or (3) taxpayers irrationally ignore the effects of taxation and insist on saving a given fraction of pretax wages for future consumption. See R. Musgrave, The Theory of Public Finance 262, 266-67 (1959). If the exempted return on assets under a wage tax contains an element of compensation for personal services, i.e., hidden wages, then the two taxes will be equivalent only if the wage tax can successfully identify wages, suggesting the administrative superiority of the consumption tax over the wage tax. See Andrews at 1183 n.I5०. Finally, the taxes may have different effects if their rates are adjusted to produce equivalent revenues. See note 2 I supra.
} 
consumption-type tax with a wage tax does not, by itself, indicate that either is less fair than an accretion-type tax. Indeed, to the extent discrimination against taxpayers with a relatively greater preference for accumulation is thought unfair, the former appear superior on equity grounds. Comprehending the identity between a wage and consumption tax does, however, make more apparent an important consequence of the latter tax base, which is that income from property escapes tax except to the extent that the applicable tax rate in the year of consumption is higher than the applicable rate in the year the invested wages were earned. Once that consequence is perceived, the question of the relative fairness of consumption-type and accretion-type taxes can be resolved only by balancing the equity argument for the former against equity considerations which call for taxation of all income from property. With the issue thus framed, we now turn to Andrews' discussion of the usual equity argument for including income from property in the tax base - the mitigation of disparities in wealth.

\section{Accumulation AND Wealth}

\section{A. Disparities in Wealth}

As Andrews puts it, the main reason for preferring an accretion-type tax to a consumption-type tax is the notion that it may reduce disparities in wealth as well as living standards. ${ }^{39}$ The current income tax is understandably rejected as ineffective in this regard. More importantly for our purposes, Andrews also argues that even if existing disparities in wealth could be adequately dealt with, taxation of accumulation as personal income might not be a desirable way to deal with the problem of wealth: to the extent accumulation represents deferred consumption, accretion-type taxation would be undesirable because of the resulting discrimination against future consumption; to the extent it exceeds deferred consumption wants, accumulation is consumption foregone, and such taxation would be undesirable for reasons which have been discussed above. ${ }^{39}$ For Andrews the arguments against taxing accumulation which is foregone or deferred consumption outweigh any equity argument for taxing income from property in order to reduce disparities in wealth.

Andrews nevertheless concedes that "wealth is a source of power," which "represents a different dimension along which to measure economic well-being." 40 Given that conclusion, the

\footnotetext{
${ }^{30}$ Andrews at 1569.
}

${ }^{40} \mathrm{Id}$. at II69-70. 
reader may be surprised to find that not only is accumulation excluded from Andrews' personal income tax base, but also that he advances no proposal for a periodic tax on net wealth. On reflection, however, it should be clear that Andrews cannot support a periodic wealth tax to mitigate such disparities because that tax would discriminate against taxpayers with a relatively greater preference for future consumption, and is therefore inconsistent with the most sophisticated argument against the accretion-type income tax. ${ }^{41}$ Indeed, any attempt to reduce discrepancies in wealth during an accumulator's lifetime is inconsistent with that argument since reduction of accumulation will necessarily raise the price of future consumption relative to present consumption.

Andrews attempts to avoid this difficulty, while adhering to the goal of reducing wealth discrepancies, by calling for stronger estate and gift taxes. However, these transfer taxes would raise the price of each taxpayer's future transfers as compared with his present consumption, which would result in discrimination against taxpayers who have a relatively greater preference to save in order to transfer wealth to their families. Andrews neither identifies that discrimination nor explains why it is acceptable when discrimination against taxpayers who have a relatively greater preference to save for their own consumption is not. ${ }^{42}$ However, two answers might suggest themselves. First, the discrimination in favor of taxpayers with a relatively greater preference for present consumption caused by the estate and gift taxes may not be quantitatively as great as that caused by an accretion-type tax. Andrews does not, however, suggest or offer support for this rationale. Second, it may be that future transfers are thought to be qualitatively different from future consumption, so discrimination against the former, but not the latter, vis-à-vis present consumption is acceptable as a matter of equity. It is presumably this type of reasoning which leads Andrews to characterize transfers as creating "a kind of unearned original disparity in wealth in the hands of a new generation." ${ }^{43}$ If so, the implied equity balance in Andrews' article is that elimination of wealth disparities between generations outweighs, as a matter of social justice, the resulting discrimination among taxpayers, while elimination of wealth disparities during the lifetime of accumulators is outweighed, as a matter of social justice, by the resulting discrimina-

${ }^{41}$ See N. KaldoR, supra note 15 , at 90.

42 The closest Andrews comes to suggesting the existence of this discrimination is by stating that deferral of the tax on accumulation until consumption or transfer "eliminates the discrimination against deferred consumption that would characterize a true accretion-type tax, at least when deferred consumption is by the same taxpayer." Andrews at II72 (emphasis added).

${ }^{43} I d$. 
tion among taxpayers. Andrews does not argue for this balance as an original matter, ${ }^{44}$ and this is not the place to examine it. Rather, what is crucial here is that the superiority, in terms of equity, of a consumption-type personal income tax over an accretion-type personal income tax depends on acceptance of that balance.

If one concluded, for instance, that taxpayers should not be able to accumulate an unlimited amount of wealth and the corresponding social power during their lifetimes without paying taxes on the accumulation, Andrews' argument would have to be rejected. That conclusion might be based either directly on a view of an equitable distribution of lifetime wealth, or on the pragmatic conclusion that taxing wealth once a generation would not sufficiently reduce disparities. ${ }^{45}$ In either case, the appropriate response to Hobbes' question would be that taxing a man on what he has earned but not consumed is necessary to achieve a fairer distribution of wealth. Reduction of the after-tax return on invested savings - the discrimination against deferred consumption - could also be justified as necessary to mitigate lifetime wealth disparities. One might, of course, prefer a wealth tax over an accretion tax as the more effective method of mitigating such disparities, ${ }^{46}$ but if the choice is limited to the consumption and accretion models for the personal income tax the latter would be preferable in terms of fairness.

In his discussion of existing wealth disparities, Andrews argues that a consumption-type tax would be preferable because it would be more progressive with regard to wealth than would an accre-

\footnotetext{
${ }^{44}$ Others have:
}

It can also be argued that if an Expenditure Tax, as opposed to an income tax, enhances the opportunity for exceptional men to make fortunes through enterprise, there is a clear social gain in increased capital accumulation, which more than offsets any tangible loss in the guise of greater social or economic inequality. (This does not of course apply to inherited wealth (...)

N. KaLDOR, supra note $\mathrm{I}_{5}$, at 50 .

[B] ut if all were done which it would be in the power of a good government to do .... to diminish the inequality of opportunities, the difference of fortune arising from people's own earnings could not justly give umbrage.

J.S. MILL, supra note 23 , bk. V, ch. $2, \S 3$ at 808 .

${ }^{45}$ Thurow, Net Worth Taxes, 25 NAT'L TAx J. 4I7, 420 (1972), calculates that an inheritance tax of $100 \%$ on transfers over $\$ 50,000$ would permit an individual who received $\$ 50,000$ at age zero and lived until 70 to accumulate $\$ 1.1$ million by age 35 and $\$ 39.5$ million by age 70 if the inheritance were invested at $10 \%$ and absolutely nothing saved from earned income. If half the return on capital income were consumed annually instead of reinvested, there would still be $\$ 1.5$ million of accumulation at age 70. Thurow concludes from such examples that even a very severe estate and gift tax would not place a very stringent constraint on the maximum amount of wealth an individual could possess. Id.

${ }^{40}$ See generally id. passim. 
tion-type tax on the assumption that at any given income level, "those with more wealth will feel free to spend more and save less." $4 \tau$ Even if this assumption were conceded, the conclusion that the consumption-type tax will be more progressive cannot be maintained if the comparison of taxpayers is not limited to a single year. Under a consumption tax, the high consumers are merely paying the deferred tax on their invested savings, while the high savers are simply deferring taxes until future consumption. Unless tax rates change, their burdens over time may be identical because, as Andrews demonstrates, the benefits of deferral achieved by the saver will be matched by a corresponding increase in future consumption tax liability. ${ }^{48}$ The problem with a single-year comparison is even clearer when the consumptiontype tax is viewed as the equivalent of a wage tax: if tax rates are constant, the high consumer and the high saver both pay what amounts to a deferred tax on prior wages; the amount of their current wealth is irrelevant. In fact, if the tax were structured as an equivalent wage tax, the low wealth taxpayer - who would have greater wages than the high wealth taxpayer with equivalent income because some of the latter's income would presumably come from property - would pay more in taxes in the single year in question, making the result regressive with regard to wealth.

\section{B. Redistribution and Graduated Rates}

Andrews also suggests that a consumption-type personal income tax can be as progressive as an accretion-type tax because graduated rates can be applied under either. ${ }^{49}$ As long as attention is focused on the retiree and the taxpayer with $\$ 800$ of current income in year 25 , there is nothing inconsistent about introducing graduated rates into the consumption-type tax. Once attention is shifted to a comparison between two taxpayers who earn the same amount, but who have different relative preferences for present and future consumption, graduated rates under a consumptiontype tax would result in discrimination against future consumption. ${ }^{50}$

Assuming a $33 \%$ tax rate on the first $\$ 100$ and a $50 \%$ tax rate on everything above that, the worker who earns $\$ 100$ in an initial year would have $\$ 67$ in after-tax consumption in that year. The retiree who saves $\$ 100$ in an initial year and invests it for 24 years at $9 \%$ would have only $\$_{4} \mathrm{I} 7$ in after-tax consumption. ${ }^{51}$ It will

${ }^{47}$ Andrews at $I 17 x$.

${ }^{48} I d$. at $X I 23-28$, II5o.

${ }^{49} I d$. at $\mathrm{YI} 74-75$.

${ }^{50}$ See C. SHOUP, supra note $2 \mathrm{I}$, at $35^{2}$.

${ }^{51}$ This result can be seen from the following computation: 
be recalled that the retiree must have $\$ 533$ in after-tax consumption to maintain his position relative to the worker who has $\$ 67$ in after-tax consumption in the initial year. ${ }^{52}$ General averaging provisions would eliminate some, but not all, of this disparity. ${ }^{53}$

In a world without taxation, the relative positions of the taxpayer who earns $\$ 800$ in year 25 , the retiree who saves and invests $\$ 100$ at $9 \%$ in the initial year, and the worker who spends $\$ 100$ in the initial year are determined by the available rate of return: a dollar in the initial year is worth 8 dollars after 24 years. A proportional consumption tax maintains their relative positions: the retiree will be able to consume the same amount as the taxpayer with $\$ 800$ of current earnings 24 years later, while they both will be able to consume eight times what the worker could consume in the initial year. Once graduated rates are introduced, however, the equality between the retiree and the taxpayer with income 24 years later can be maintained only by distorting the relative positions of the retiree and the worker who consumed in the initial year. Since the only difference between the retiree and that worker is their relative preference for present and future consumption, the resulting discrimination against the retiree the taxpayer with the relatively greater preference for future consumption - is inconsistent with the best argument for adopting the consumption model to begin with. Thus the consumption-type personal income tax must either be limited to a proportional rate or suffer the defect Andrews finds so fatal in the accretion model. ${ }^{54}$

$$
\begin{aligned}
\text { After-tax income } & =800-[0.33 \times 100]-[0.50 \times(800-100)] \\
& =800-33-350 \\
& =417
\end{aligned}
$$

${ }^{52}$ See pp. $935-36$ supra.

${ }^{53}$ Such provisions are suggested in Andrews at 1557 . Without averaging, a graduated consumption-type tax could result in a greater tax burden for current consumers than for deferred consumers, depending on their spending patterns. For example, a consumer who earned and spent $\$ 10,000$ in a single year might pay more in taxes than an otherwise comparable taxpayer who earned $\$ 10,000$ in one year, but divided his spending evenly between two years. The differential in taxation, which favors the deferred consumer in this example, results from bunching of expenditures and would be eliminated by lifetime averaging.

But if consumption were averaged over a lifetime, a graduated consumptiontype tax would discriminate against deferred consumption. A current consumer would have less total-dollar consumption than an equal wage earner who defers consumption since the latter increases the dollar amount available for consumption by the return on invested savings. Inclusion of that increment under a proportional consumption-type tax just offsets the benefits of deferral. Graduated brackets would subject the increment received by deferred consumers to higher rates, so future consumption would be made more expensive relative to present consumption.

${ }^{54} \mathrm{~A}$ graduated wage tax would not be subject to this objection, but Andrews concludes that the best argument for progressivity requires tax rates to be applied in the spending, rather than earning, period. See id. at II76-77. 


\section{ConcLusion}

That taxpayers may respond to a tax by reducing consumption in order to pay the government its due does not establish that the fairest index of taxability is consumption. Nor does the Hobbesian view of accumulation as the excess of what one has contributed to production over what one has withdrawn necessarily make taxation of the excess unfair, since the accumulator continues to control the excess for his own benefit.

Assuming the appropriate effect on interest rates, an accretiontype personal income tax will change the relative positions of taxpayers who have different preferences for present and future consumption by reducing the after-tax return on invested savings. To the extent that reduction is considered unfairly discriminatory, it must be weighed against the inability of a consumption-type personal income tax to mitigate lifetime disparities in wealth. That inability derives from the effective exclusion from the tax base of income from property, making a consumption-type tax the equivalent of a wage tax when rates are constant. If mitigation of lifetime wealth disparities were considered an important goal of a fair tax system, reducing the after-tax return on invested savings might be tolerated as a necessary cost of achieving that goal.

Introducing graduated rates into the consumption tax does not help to resolve the dilemma since their effect is inconsistent with the reason for rejecting an accretion-type tax to begin with. Instead, the choice between the consumption and accretion models for the personal income tax, as a matter of fairness, comes down to a choice between mitigation of lifetime wealth disparities and preservation of the pretax relative price of present and future consumption as the more important equity goal. One's ethical predilections rather than logic - at least legal or economic logic - have to provide the grounds for making that choice. 